\title{
Clinical and Demographic Features of Pseudotumor Cerebri Syndrome Diagnosed in a University Hospital
}

\author{
Bir Üniversite Hastanesi Tarafından Psödotümör Serebri Sendromu Tanısı Konan \\ Hastaların Klinik ve Demografik Özellikleri
}

\author{
Demet Arslan, Adalet Arıkanoğlu, Eşref Akıl
}

Dicle University Faculty of Medicine, Department of Neurology, Diyarbakır, Turkey

\begin{abstract}
Objective: Pseudotumor cerebri syndrome (PTCS) is characterized by symptoms and signs of increased intracranial pressure without ventriculomegaly, intracranial tumor or mass. This study aimed to explore and analyze 34 patients with PTCS according to age, sex, symptoms of the disorder, cranial magnetic resonance images findings, etiology, and treatment.

Materials and Methods: A total of 34 patients who were diagnosed as having PTCS and followed up between January 2011 and August 2016 by Dicle University Medical School Neurology Department were included in this study. PTCS was diagnosed in accordance with the modified Dandy criteria.

Results: Thirty-four patients were identified as having PTCS. Twenty-one (91.2\%) had headache, 19 (55.9\%) had blurred vision, 6 (17.6\%) had diplopia, 2 (5.9\%) had vertigo, $1(2.9 \%)$ had tinnitus, and $1(2.9 \%)$ had numbness of the face. Twenty-seven patients were diagnosed as having idiopathic intracranial hypertension, 21 $(61.8 \%)$ had no etiologic factors. Six (17.6\%) patients were obese, one of whom had recently gained weight and another had polycystic ovary syndrome. Seven patients were thought to have secondary PTCS with the following etiologic factors: $2(5.9 \%)$ patients had Hashimoto's thyroiditis, 1 (2.9\%) had a history of all-trans retinoic acid intake due to a malignancy, 1 (2.9\%) had choroid plexus granuloma, 2 (5.9\%) had sinus venous thrombosis, and 1 (2.9\%) had Familial Meditteranian Fever.

Conclusion: Although PTCS was described many years ago, its physiopathology and exact treatment procedures are not clearly understood. The most important target of its treatment is to prevent loss of vision and improve symptoms. With a better understanding of its pathophysiology, effective treatment protocols will be developed.
\end{abstract}

Keywords: Idiopathic intracranial hypertension, pseudotumor cerebri syndrome, headache

\section{$\ddot{O} \mathbf{z}$}

Amaç: Psödotümör serebri sendromu (PTSS) ventrikülomegali, intrakraniyal tümör veya kitle olmaksızın intrakraniyal basıncın (İKB) arttığı bir sendromdur. Bu çalışmada kliniğimizde PTSS tanısı ile takip edilen 34 hastanın yaş, cinsiyet dağılımı, semptomları, kraniyal manyetik rezonans görüntüleme bulguları, etiyolojileri ve tedavileri tartışılmaktadır.

Gereç ve Yöntem: Bu çalışmada Ocak 2011 ile Ağustos 2016 tarihleri arasinda Dicle Üniversitesi Tıp Fakültesi Hastanesi Nöroloji Kliniği nde PTSS tanısı ile takip edilen 34 hasta gözden geçirildi. PTSS tanısı için revize edilmiş modifiye Dandy kriterleri kulanıldı.

Bulgular: Olguların 31'inde $(\% 91,2)$ baş ağrısı, 19'unda $(\% 55,9)$ bulanık görme, 6'sında $(\% 17,6)$ diplopi, 1'inde $(\% 2,9)$ tinnitus, 1'inde $(\% 2,9)$ yüzde uyuşma, 2 'sinde $(\% 5,9)$ vertigo yakınması vardı. Yirmi yedi hasta idiyopatik intrakraniyal hipertansiyon (İ̈H) olarak kabul edildi. Yirmi bir hastada (\%61,8) etiyoloji saptanamadı. Altı hastada $(\% 17,6)$ obezite, bunların 1 tanesinde yakın zamanda kilo alma öyküsü, 1 tanesinde de polikistik over sendromu saptandı. Yedi hastada sekonder PTSS düşünüldü. Sekonder sebepler olarak; 2 hastada $(\% 5,9)$ Hashimoto tiroiditi, 1 hastada $(\% 2,9)$, malignite nedeniyle all-trans retinoik asit kullanımı, 1 hastada $(\% 2,9)$ koroid pleksus granülomu, 2 hastada $(\% 5,9)$ sinüs trombozu, 1 hastada $(\% 2,9)$ Ailesel Akdeniz Ateşi etiyolojik neden olarak saptandı.

Address for Correspondence/Yazışma Adresi: Demet Arslan MD, Dicle University Faculty of Medicine, Department of Neurology, Diyarbakır, Turkey Phone: +90 5053121388 E-mail: demet08@gmail.com

Received/Gelis Tarihi: 14.02.2017 Accepted/Kabul Tarihi: 20.03 .2017 Presented in: $52^{\text {nd }}$ National Neurology Congress as a poster.

${ }^{\odot}$ Copyright 2017 by Turkish Neurological Society Turkish Journal of Neurology published by Galenos Publishing House. 
Öz

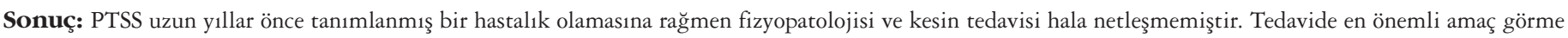
kaybının önlenmesi ve semptomların giderilmesidir. Patofizyolojinin aydınlatılmasıyla daha etkin tedavi yöntemleri geliştirilecektir.

Anahtar Kelimeler: İdiyopatik intrakraniyal hipertansiyon, psödotümör serebri sendromu, baş ağrısı

\section{Introduction}

Pseudotumor cerebri syndrome (PTCS) is characterized by increased intracranial pressure (ICP) in the absence of ventriculomegaly, intracranial tumor or mass (1). It is actually a hypernym, and includes primary [idiopathic intracranial hypertension (IIH)] and secondary intracranial hypertension (2). Its clinical manifestations are headache, photophobia, nausea, pulsatile tinnitus, loss of vision, and diplopia (1). The clinical presentation is highly variable, which leads to delays in diagnosis. If untreated, permanent vision loss may occur (3). It is typically seen in obese and fertile women with an incidence of 12-20/100,000 person/year in this group, and the incidence is $0.5-2 / 100,000$ in the general population (3). The disease was first described by Quincke (4) in 1893 and named "meningitis serosa". Later, in 1937, Dandy reported a set of 22 patients and some diagnostic criteria. Over the years, the criteria defined by Dandy have undergone some changes and were revised finally by Friedman et al. (2) in 2013 (5). The treatment is to decrease cerebrospinal fluid (CSF) pressure through reducing CSF production or drainage (1).

In this study, age, sex distribution, symptoms, cranial magnetic resonance imaging (MRI) findings, etiology, and treatment of 34 patients with PTCS followed in our clinic are discussed.

\section{Materials and Methods}

In this study, 34 patients who were followed up with a diagnosis of PTCS at the Neurology Clinic of Dicle University Hospital between January 2011 and August 2016 were reviewed. The modified Dandy criteria were used to diagnose PTCS. The age, sex, symptoms, fundoscopic examination, CSF pressure, cranial MRI and MR venography findings, etiology, and treatment of each patient were examined. All patients had systemic, neurologic and ophthalmologic examinations, appropriate laboratory examinations, and cranial imaging studies. Microscopy, biochemical analysis, and microbiologic studies were performed from the obtained CSF samples.

According to the modified Dandy criteria, patients who fulfilled all of the following diagnostic criteria were diagnosed as having definite PTCS.

a. Papilledema,

b. Normal neurologic examination findings - except cranial nerve abnormalities,

c. Normal neuroimaging findings: absence of hydrocephalus, mass, structural lesion and abnormal meningeal involvement,

d. Normal CSF composition,

e. Increased CSF opening pressure $\left(\geq 250 \mathrm{mmH}_{2} \mathrm{O}\right)$ with appropriately performed lumbar puncture (LP).

For the diagnosis of PTCS without papilledema, unilateral or bilateral abducens nerve paralysis along with criteria b-e must be fulfilled.
If there is no papilledema or $6^{\text {th }}$ cranial nerve paralysis, PTCS diagnosis can be suggested, but a definite diagnosis cannot be made.

In order to be able to recommend a PTCS diagnosis, there should be at least 3 of the following MRI findings in addition to criteria b-e:

1. Empty sella (empty sella),

2. Posterior globe flattening,

3. Distension of perioptic subarachnoid space (may or may not be accompanied by tortuous optic nerve),

4. Transverse venous sinus stenosis (2).

\section{Results}

Twenty-six $(76.5 \%)$ of the 34 patients were female and 8 $(23.5 \%)$ were male. The mean age was 37 years (range, 18-80 years). The mean $\mathrm{CSF}$ pressure was $34 \mathrm{cmH}_{2} \mathrm{O}$ (range, 25-60 cmH2O). Thirty-one (91.2\%) patients had headache, $19(55.9 \%)$ had blurred vision, 6(17.6\%) had diplopia, 1 (2.9\%) had tinnitus, 1 had facial numbness and $2(5.9 \%)$ had vertigo (Table 1$)$. Although six patients reported diplopia, $6^{\text {th }}$ cranial nerve palsy was detected in only one patient. Two $(5.8 \%)$ patients had migraine headaches. Cranial MRI findings were as follows: normal in $14(41.2 \%)$, thin pituitary in $15(44.1 \%)$, empty sella in $5(14.7 \%)$, optic nerve tortuosity in $6(17.6 \%)$, indentation in the posterior globe in 1 $(2.9 \%)$, and distension of perioptic CSF distance in $18(52.9 \%)$ patients. Sinus hypoplasia was detected in MR venography in 5 (14.7\%) patients (Table 2). Twenty-seven patients were accepted as IIH. No etiology was found in $21(61.8 \%)$ patients. Six (17.6\%) patients had obesity; 1 had a recent history of weight gain and 1 had polycystic ovarian syndrome (PCOS). Seven patients were considered as having secondary PTCS. Secondary reasons were as follows: Hashimoto's thyroiditis in $2(5.9 \%)$ patients, use of alltrans retinoic acid (ATRA) in 1 patient (2.9\%) for malignancy, choroid plexus granuloma in $1(2.9 \%)$ patient, sinus thrombosis in $2(5.9 \%)$ patients, and Familial Mediterranean Fever in 1 $(2.9 \%)$ patient (Table 3$)$. Concentric narrowing of the visual field was observed in $15(51.7 \%)$ of patients; the visual field results of 5 patients could not be retrieved.

\begin{tabular}{|lcc|}
\hline \multicolumn{3}{|c|}{ Table 1. Clinical findings of patients } \\
\hline Clinical findings & Patients (n) & $\%$ \\
Headache & 31 & 91.2 \\
Blurred vision & 19 & 55.9 \\
Diplopia & 6 & 17.6 \\
Tinnitus & 1 & 2.9 \\
Facial numbness & 1 & 2.9 \\
Vertigo & 2 & 5.9 \\
\hline
\end{tabular}


Only 14 patients (41.2\%) were treated with acetazolamide and the maximum dosage was 1500 milligrams/day. Topiramate was added to the treatment of $16(47.1 \%)$ patients and steroids were given to $4(11.8 \%)$ patients.

\section{Discussion}

PTCS is a disease with increased ICP due to an unknown etiology. Although the symptoms and findings are well-defined, the pathogenesis is still unknown. It is thought that there is increased resistance to CSF flow (1). Although it is typically seen in obese and fertile women, it can also be seen in nonobese patients and children (3). The incidence is $2 / 100,000$ in the whole population and higher in the obese. With increasing obesity in the world, the incidence of PTCS is also increasing. Before puberty, the female/male ratio is equal and secondary PTCS is commonly seen $(6,7)$. When seen in males, secondary causes should be well researched (1). Of the patients in our series, $26(76.5 \%)$ were female and 8 were male $(23.5 \%)$. The mean age of diagnosis is 25-36 years in the literature (3). The mean age in our study was 37 years (range, 18-80 years). It is known that chronic headache and loss of vision are the main presentations. The most common symptom is headache and it is seen in 80$90 \%$ of patients. The disease results in blindness in about $10 \%$ of patients. Other symptoms that may be seen include blurred vision, loss of vision, diplopia (due to undefined sixth cranial nerve paralysis), pulsatile tinnitus, and vertigo $(6,8,9)$. Headache can be typically bilateral frontal or retro-orbital, pulsating or in the form of pressure sensation. Some patients have chronic daily headaches. Sometimes it can be difficult to distinguish PTCS headache from other primary headaches. For example, premorbid

\begin{tabular}{|lcc|}
\hline \multicolumn{3}{|c|}{ Table 2. Magnetic resonance imaging findings } \\
\hline MRI findings & Patients (n) & $\%$ \\
Normal & 14 & 41.2 \\
Distended perioptic CSF space & 18 & 52.9 \\
Thin hypophysis & 15 & 44.1 \\
Optic nerve tortuosity & 6 & 17.6 \\
Empty sella & 5 & 14.7 \\
Sinus hypoplasia & 5 & 14.7 \\
Indentation in posterior globe & 1 & 2.9 \\
CSF: Cerebrospinal fluid, MRI: Magnetic resonance imaging & \\
\hline
\end{tabular}

\begin{tabular}{|lcc|}
\hline \multicolumn{4}{c|}{ Table 3. Etiological reasons } \\
Etiology & Patients (n) & $\%$ \\
Obesity & 6 & 17.6 \\
Hashimoto thyroiditis & 2 & 5.9 \\
Sinus thrombosis & 2 & 5.9 \\
ATRA & 1 & 2.9 \\
FMF & 1 & 2.9 \\
Choroid plexus granuloma & 1 & 2.9 \\
ATRA: All-trans retinoic acid, FMF: Familial Mediterranean fever & \\
\hline
\end{tabular}

migraine headaches have been reported in $41 \%$ of patients. Drug overuse headache and chronic tension headache are among the headaches that can interfere with PTCS $(10,11)$. In this study, migraine headache was detected also in $2(5.8 \%)$ patients. Symptoms of headache, blurred vision, diplopia, tinnitus, and vertigo were observed in our patient group in accordance with the literature, but facial numbness, which was not previously defined, was also observed. The loss of vision in patients with PTCS is thought to be due to papilloma and secondary optic neuropathy, and almost all patients have papilledema. Papilledema is usually bilateral and symmetric, but may be mildly asymmetric or unilateral (10\%) (9). In our study, unilateral papilledema was detected in $4(11.8 \%)$ patients. Peripheral narrowing, nasal step, and arcuate scotoma are the most common visual field defects (12). Peripheral vision loss is insidious and many patients are unaware of minor deficits because central vision is preserved until late periods. There may also be a rare acute loss of vision (9). The sixth cranial nerve is the most affected cranial nerve from increased ICP, which results in binocular horizontal diplopia. It may be unilateral or bilateral (10). In our study, the diplopia rate was detected as $17.6 \%$. Intermittent tinnitus has been reported in $52 \%$ of patients, which reults from the turbulence in blood flow caused by the compressive effect of intracranial hypertension on the venous sinuses (10). In our study, we detected tinnitus in only one $(2.9 \%)$ patient.

There are many theories about the pathogenesis of the disease. It is believed that altered CSF dynamics, obesity, sex hormones, and underlying prothrombotic abnormalities play a role in the pathogenesis (13). The reason for the frequent occurrence of primary PTCS in obese and fertile women is attributed to the effects of female sex hormones and endocrine lipoproteins in genetically predisposed individuals. Although the mechanisms of action are unknown, it is thought that ICP increase may be due to mineralocorticoids, one of the substances released from fat tissue, which causses an increase in CSF production, prothrombotic effect of estrogen (venous sinus thrombosis-microthrombotic obstruction of arachnoid villi) and mineralocorticoid effect of progesterone (1). Cerebral venous sinus anomalies (cerebral venous sinus thrombosis, bilateral juguler ven thrombosis, middle ear or mastoid infection, hypercoagulability), drug use (some antibiotics such as tetracycline, steroid withdrawal, hypervitaminosis A, isoretinin, ATRA and lithium) and some diseases (hypoparathyroidism, Addison's disease, sleep apnea syndrome, anemia, renal failure) can be counted among the causes of secondary PTCS. Obesity, recent weight gain, and PCOS are considered in the context of primary PTCS (2). Neuroimaging in PTCS is mainly used to exclude secondary causes that may lead to increased ICP. Recently, however, some small changes such as empty sella, posterior globe flattening, intraocular protrusion of optic nerve, optic nerve tortuosity, distension of perioptic subarachnoid space, and transverse sinus stenosis have been reported to be indicative of PTCS (14). Empty sella is the most commonly reported finding in patients with IIH (15). Although empty sella is used for diagnosis in the literature, partial empty sella and thinned pituitary gland are also reported to be a common finding in these patients. In the study by Görkem and colleagues, smaller pituitary glands, rather than empty sella, were found in patients 
with PTCS compared with the healthy controls (14). In our series, empty sella was seen in $5(14.7 \%)$ patients and thinner pituitary gland was detected in $15(44.1 \%)$ patients. Farb et al. demonstrated bilateral distal transverse sinus stenosis with $93 \%$ sensitivity in patients with IIH using a new MRI technique (16). However, bilateral transverse sinus stenosis was detected at a rate of $97 \%$ in studies using various MRI techniques. It can be detected incidentally even in healthy people. According to the modified Dandy criteria, bilateral transverse sinus stenosis is a minor diagnostic criterion (15). In our study, sinus stenosis was also detected in $5(14.7 \%)$ patients. As seen, there are no pathognomonic radiologic findings, although there are many radiologic findings that are suggestive of PTCS (10).

Treatment depends on symptoms and status of loss of vision (9). The main goal of the treatment is to prevent vision loss and to reduce symptoms associated with increased ICP (10). Asymptomatic patients with normal vision and minimal papillary edema are followed up. The treatment protocol is conservative in patients with normal vision and analgesic-controlled headaches (9). The treatment protocol consists of medical, CSF drainage via LP, and surgical methods. The main factor in medical treatment is weight loss. Aggressive weight loss is recommended in obese patients $(10,17)$. Medical treatment is performed in patients with mild to moderate vision loss. Medical treatment usually resolves papilledema within weeks or months (9). Acetazolamide is the first choice for treatment. Other agents that may be used are furosemide, prednisone, and topiramate (18). In our study, acetazolamide alone was effective in $14(41.2 \%)$ patients, and was used in combination with topiramate in $16(47.1 \%)$ patients. Four $(11.8 \%)$ patients received steroid treatment. Surgery was not considered in any patients. Despite maximum medical care, resistant headache, severe or progressive vision loss requires surgical treatment.

\section{Conclusion}

PTCS is characterized by headache in young obese women and its etiology is unknown. It can be diagnosed as a primary headache such as migraine and tension-type headache by the diversity of age, sex, and headache criteria. This disease can cause severe neurologic deficits such as irreversible loss of vision. In patients with a diagnosis of possible primary headache that does not meet the diagnostic criteria of primary headache, detailed history, detailed examination, and further examination may be required to exclude PTCS. For better recognition of PTCS, there is a need for broader studies to clarify the pathophysiology, amd clinical and imaging criteria.

\section{Ethics}

Ethics Committee Approval: Retrospective study, Informed Consent: Retrospective study.

Peer-review: Externally peer-reviewed.

\section{Authorship Contributions}

Concept: D.A., Design: D.A., Data Collection or Processing: D.A., A.A., Analysis or Interpretation: A.A., Literature Search: A.A., Writing: D.A., E.A.

Conflict of Interest: No conflict of interest was declared by the authors.

Financial Disclosure: The authors declared that this study received no financial support.

\section{References}

1. McGeeney BE, Friedman DI. Pseudotumor cerebri pathophysiology. Headache 2014;54:445-458.

2. Friedman DI, Liu GT, Digre KB. Revised diagnostic criteria for the pseudotumor cerebri syndrome in adults and children. Neurology 2013;81:1159-1165

3. Markey KA, Mollan SP, Jensen RH, Sinclair AJ. Understanding idiopathic intracranial hypertension: mechanisms, management, and future directions. Lancet Neurol 2016;15:78-91.

4. Quincke H. Meningitis serosa. Samml Klin Vortr 1893;67:655.

5. Spennato P, Ruggiero C, Parlato RS, Buonocore MC, Varone A, Cianciulli E, Cinalli G. Pseudotumor cerebri. Childs Nerv Syst 2011;27:215-235.

6. Hainline C, Rucker JC, Balcer LJ. Current concepts in pseudotumor cerebri. Curr Opin Neurol 2016;29:84-93.

7. Paley GL, Sheldon CA, Burrows EK, Chilutti MR, Liu GT, McCormack SE. Overweight and obesity in pediatric secondary pseudotumor cerebri syndrome. Am J Ophthalmol 2015;159:344-352.

8. Mallery RM, Friedman DI, Liu GT. Headache and the pseudotumor cerebri syndrome. Curr Pain Headache Rep 2014;18:446.

9. Almarzouqi SJ, Morgan ML, Lee AG. Idiopathic intracranial hypertension in the Middle East: A growing concern. Saudi J Ophthalmol 2015;29:26-31.

10. Julayanont P, Karukote A, Ruthirago D, Panikkath D, Panikkath R. Idiopathic intracranial hypertension: ongoing clinical challenges and future prospects. J Pain Res 2016;9:87-99.

11. Wall M, Kupersmith MJ, Kieburtz KD, Corbett JJ, Feldon SE, Friedman DI, Katz DM, Keltner JL, Schron EB, McDermott MP; NORDIC Idiopathic Intracranial Hypertension Study Group. The idiopathic intracranial hypertension treatment trial: clinical profile at baseline. JAMA Neurol 2014;71:693-701.

12. Celebisoy N, Gokcay F, Sirin H, Akyurekli O. Treatment of idiopathic intracranial hypertension: topiramate vs acetazolamide, an open-label study. Acta Neurol Scand 2007;116:322-327.

13. Dhungana S, Sharrack B, Woodroofe N. Idiopathic intracranial hypertension. Acta Neurol Scand 2010;121:71-82.

14. Görkem SB, Doğanay S, Canpolat M, Koc G, Dogan MS, Per H, Coşkun A. MR imaging findings in children with pseudotumor cerebri and comparison with healthy controls. Childs Nerv Syst 2015;31:373-380.

15. Bidot S, Saindane AM, Peragallo JH, Bruce BB, Newman NJ, Biousse V. Brain Imaging in Idiopathic Intracranial Hypertension. J Neuroophthalmol 2015;35:400-411.

16. Farb RI, Vanek I, Scott JN, Mikulis DJ, Willinsky RA, Tomlinson G, terBrugge KG. Idiopathic intracranial hypertension: the prevalence and morphology of sinovenous stenosis. Neurology 2003;60:1418-1424.

17. Degnan AJ, Levy LM. Pseudotumor cerebri: brief review of clinical syndrome and imaging findings. AJNR Am J Neuroradiol 2011;32:1986-1993.

18. Per H, Canpolat M, Gümüş H, Poyrazoğlu HG, Yıkılmaz A, Karaküçük S, Doğan H, Kumandaş S. Clinical spectrum of the pseudotumor cerebri in children: etiological, clinical features, treatment and prognosis. Brain Dev 2013;35:561-568. 